\title{
Preculture Medium Promotes Direct Shoot Regeneration from Micropropagated Strawberry Leaf Disks
}

\author{
S. Sorvari, S. Ulvinen, T. Hietaranta, and H. Hiirsalmi \\ Agricultural Research Center, Institute of Horticulture, SF-21500 Piikkiö, \\ Finland
}

Additional index words. Fragaria $\times$ ananassa, organogenesis

\begin{abstract}
The effect of preculturing in vitro plantlets of two strawberry (Fragaria xananassa Duch.) cultivars grown on micropropagation medium with and without hormones on regenerating shoots from leaf disks was examined. Preculturing stock plants on micropropagation medium with hormones (BAP at $0.5 \mathrm{mg}^{-1 i t e r}{ }^{-1}+\mathrm{IBA}$ at $0.5 \mathrm{mg} \cdot \mathrm{liter}^{-1}$ GA, at $0.2 \mathrm{mg}^{-1 i t e r^{-1}}$ ) promoted shoot regeneration in the two cultivars tested. Using hormone-containing micropropagation medium for preculture, the highest mean regeneration rate of 9.9 shoots per total number of leaf disks was obtained for the Finnish cultivar Hiku on modified Murashige and Skoog (MS) regeneration medium supplemented with (in mg-liter ${ }^{-1}$ ) $2000 \mathrm{KNO}_{3}, 400$ casein hydrolysate $(\mathrm{CH}), 3$ BAP, and 0.1 IBA. For the Norwegian cultivar Jonsok, the highest mean regeneration rate of 12.8 shoots per total number of leaf disks was obtained on modified MS regeneration medium with (in mg-liter ${ }^{-1}$ ) $600 \mathrm{CH}, 3$ BAP, and 0.1 IBA. Chemical names used: 6-benzylaminopurine (BAP); 3-indolebutyric acid (IBA); gibberellic acid $\left(\mathbf{G A}_{3}\right)$.
\end{abstract}

Regenerating plants from somatic cells has aroused extensive interest among plant breeders andmolecular biologists. There are several methods of regenerating plants (Hicks, 1980; Reinert, 1968), including callus formation induction followed by shoot regeneration from calli or direct shoot formation from single cells of wounded tissue or cell suspensions. In plants regenerated from callus cultures, somaclonal variation may occur in agriculturally important characters that can improve crops (Evans, 1989; Jones et al., 1988; Nehra et al., 1990c). However, when genetic stability is desired, direct shoot formation is an appropriate regeneration method. Nehra et al. ( 1989) found that the morphology of plants directly regenerated from 'Redcoat' strawberry leaf disks was identical to that of the mother plant.

Desirable micropropagation features and gene transfer techniques include high shoot regeneration rate and high genetic stability in the regenerated plants. Efficient shoot regeneration (Jones et al., 1988; Nehra et al., 1989,

Received for publication 23 Jan. 1992. Accepted for publication 14 Sept. 1992. The cost of publishing this paper was defrayed in part by the payment of page charges. Under postal regulations, this paper therefore must be hereby marked advertisement solely to indicate this fact. 1990c) and genetic transformation (James et al., 1990; Nehra et al., 1990a, 1990b) protocols have been designed recently for some North American and European strawberry cultivars. However, such protocols are still lacking for important cultivars cultured in Finland.

Shoot regeneration directly from fieldgrown strawberry plants (Nehra et al., 1989) and from callus cultures initiated from material grown in vitro (Jones et al., 1988; Nehra et al., 1990c) has been reported. The purpose of the present study was to compare the effects of several preculture media to develop a regeneration method from leaf disks for commonly grown strawberry cultivars. This method's main applications are transferring alien genes into strawberry plants and micropropagation, but the method can also be used to identify possible differences between plants regenerated directly from somatic cells and those regenerated from callus cultures. We report on direct shoot regeneration from strawberry leaf disks obtained from in vitro-micropropagated material.

Plant material. Virus-free in vitro stock plants of the Finnish 'Hiku' strawberry and the Norwegian 'Jonsok' strawberry were obtained from the Healthy Plant Center at Laukaa (Finland) Research Station. 'Hiku' stock plants were 19 months old and 'Jonsok' 22 months, as counted from the first meristem isolation. Both strawberry cultivars were derived from a single micropropagated mother plant. Stock plants were kept on $\mathrm{G}$ medium (Uosukainen, 1991) under a 16-h photoperiod (40 to 50 $\left.\mathrm{pmol} \cdot \mathrm{m}^{-2} \cdot \mathrm{s}^{-1}\right)$ at $25 \pm 1 \mathrm{C}$ during the day and 23 $\pm 1 \mathrm{C}$ at night. The plants were transferred every 4 weeks to fresh $\mathrm{G}$ medium.

Preparing explants and culture media. Four-week-old micropropagated plants were transferred to $\mathrm{G}$ medium with or without hormones [(in mg.liter ${ }^{-1}$ ) 0.5 BAP, 0.5 IBA, and $0.2 \mathrm{GA}_{3}$ ] and incubated for 4 weeks under the same conditions as the stock plants. After 4 weeks, 4-mm-diameter leaf disks were punched from leaves using a cork borer and transferred to 50-mm-diameter petri dishes containing 11 $\mathrm{ml}$ of modified regeneration medium. To reduce the possible influence of the leaf's developmental stage, the disks were distributed randomly among the different nutrient media. The modified regeneration medium consisted of Murashige and Skoog's (1962) mineral salts supplemented with $30 \mathrm{~g}$ sucrose, $8 \mathrm{~g}$ Difco Bacto-Agar, and $39 \mathrm{mg} \mathrm{Fe}$ (III)NaEDTA/liter and various combinations of $\mathrm{KNO}_{3}$ and growth hormones, as suggested by Liu and Sanford (1988) (Table 1). The $\mathrm{pH}$ was adjusted to 5.7 before autoclaving for $20 \mathrm{~min}$ at $121 \mathrm{C}$ and $103 \mathrm{kPa}$.

Experimental procedure. Each treatment consisted of six replications with four leaf disks per replication. Leaf disks forming shoots and shoots per leaf disk were counted after 8 weeks. The number of shoots per leaf disk was expressed as a ratio of total number of shoots per total number of leaf disks. The experiments were completely randomized; the data were not transformed. The differences among treatments were tested with analysis of variance. Paired comparisons were made with the paired $t$ test.

Preculture on $G$ micropropagation medium without hormones. Both 'Jonsok' and 'Hiku' showed a relatively low regeneration rate after being pretreated on hormone-free micropropagation medium (Table 1).

The highest mean number of shoots for 'Jonsok' (total disk number $=$ TDN) was achieved on medium A with $3 \mathrm{mg}$ BAP/liter, and the lowest on medium D with $5 \mathrm{mg}$ BAP/liter (Table 1). Differences among treatments for number of shoots produced per leaf disk were significant at $P=0.01$. The percentage of leaf disks forming shoots was higher on media A and $\mathrm{D}$ than on $\mathrm{B}$ and $\mathrm{C}$, but none of the differences were significant. Shoot quality was somewhat better on media A and C (3 mg 
Table 1. Effect of preculture of in vitro stock plants on shoot regeneration from leaf disks of 'Jonsok' and 'Hiku' strawberries.

\begin{tabular}{|c|c|c|c|c|}
\hline \multirow[b]{2}{*}{ Medium $^{x}$} & \multicolumn{2}{|c|}{ No. shoots/leaf disk ${ }^{z}$} & \multicolumn{2}{|c|}{ Leaf disks forming shoots (\%) } \\
\hline & $\begin{array}{c}\text { Preculture } \\
\text { without } \\
\text { hormones }\end{array}$ & $\begin{array}{c}\text { Preculture }^{y} \\
\text { with } \\
\text { hormones }\end{array}$ & $\begin{array}{c}\text { Preculture } \\
\text { without } \\
\text { hormones }\end{array}$ & $\begin{array}{c}\text { Preculture } \\
\text { with } \\
\text { hormones }\end{array}$ \\
\hline & & & & \\
\hline A & 6.1 & $12.8 * * *$ & 25.0 & 81.8 \\
\hline B & 3.3 & $8.0^{* * * *}$ & 20.5 & 85.4 \\
\hline $\mathrm{C}$ & 4.6 & $9.2^{* * *}$ & 16.7 & 83.3 \\
\hline $\mathrm{D}$ & 1.3 & $6.9 * * *$ & 25.0 & 79.2 \\
\hline \multirow[t]{3}{*}{$\mathrm{E}$} & -- & 11.7 & --- & 83.3 \\
\hline & $* *$ & NS & NS & NS \\
\hline & & & & \\
\hline A & 1.5 & $8.5 * * *$ & 56.3 & 64.6 \\
\hline B & 1.3 & $7.5^{*}$ & 50.0 & 60.4 \\
\hline C & 0.6 & $9.9 * * *$ & 43.8 & 75.0 \\
\hline $\mathrm{D}$ & 1.0 & $9.1 * * *$ & 37.5 & 66.7 \\
\hline \multirow[t]{2}{*}{$\mathrm{E}$} & --- & 3.1 & --- & 43.8 \\
\hline & NS & NS & NS & NS \\
\hline
\end{tabular}

${ }^{2}$ Total number of shoots/total number of leaf disks.

Significance is based on comparison with preculture without hormones.

Composition of media; concentration in $\mathrm{mg} \cdot \mathrm{liter}^{-1}$ :

A: $\mathrm{MS}+1900 \mathrm{KNO}_{3}+600 \mathrm{CH}+3 \mathrm{BAP}+0.1 \mathrm{IBA}$.

B: $\mathrm{MS}+1900 \mathrm{KNO}_{3}+600 \mathrm{CH}+5 \mathrm{BAP}+0.1 \mathrm{IBA}$

C: $\mathrm{MS}+2000 \mathrm{KNO}_{3}+400 \mathrm{CH}+3 \mathrm{BAP}+0.1 \mathrm{IBA}$.

$\mathrm{D}: \mathrm{MS}+2000 \mathrm{KNO}+400 \mathrm{CH}+5 \mathrm{BAP}+0.1 \mathrm{IBA}$.

$\mathrm{E}: \mathrm{MS}+2000 \mathrm{KNO}_{3}+400 \mathrm{CH}+1.5 \mathrm{BAP}+0.1 \mathrm{IBA}$.

MS = Murashige and Skoog's mineral salts; $\mathrm{CH}=$ casein hydrolysate .

${ }^{\text {ss }}, *, * *, * * *$ Nonsignificant or significant at $P=0.01,0.05$, or 0.001 , respectively.

BAP/liter) than on B and D (5 mg BAP/liter), where they were composed of small, tight meristemoids or tiny shoots. In addition, the shoots on media $\mathrm{B}, \mathrm{C}$, and $\mathrm{D}$ were vitreous and their separation was difficult.

After preculturing the disks on hormonefree micropropagation medium, 'Hiku' shoot regeneration was low (Table 1). The mean regeneration rate per total number of leaf disks varied from 0.6 on medium $\mathrm{C}$ to 1.5 on medium $\mathrm{A}$, but the differences among treatments were not significant. As compared with 'Jonsok', the percentage of shoot-producing disks was high in 'Hiku': it ranged from 56\% on medium $\mathrm{A}$ to $37 \%$ on medium $\mathrm{D}$. The different media had only a minor impact on 'Hiku' shoot quality. All the regenerated shoots were fairly large, had good chlorophyll formation, and separated easily.

Preculture on $G$ micropropagation medium with hormones. In 'Jonsok', when leaf disks were obtained from stock plants maintained on micropropagation medium containing hormones, medium A with $3 \mathrm{mg} \mathrm{BAP} / \mathrm{liter}$ again produced the highest number of shoots $(12.8 / \mathrm{TDN})$, which was about twice as many as for material not pretreated with hormones (Table 1). BAP at $1.5 \mathrm{mg} \cdot$ liter $^{-1}$ with $400 \mathrm{mg}$ of casein hydrolysate $(\mathrm{CH})$ (medium $\mathrm{E}$ ) was also tested, and the regeneration rate was almost the same as on medium A.

The percentage of leaf disks forming shoots was similar for all media (Table 1), but shoot quality varied among media. On media B and $\mathrm{D}$, with $5 \mathrm{mg} \mathrm{BAP/liter,} \mathrm{the} \mathrm{shoots} \mathrm{were} \mathrm{small}$ and they tended to form tight bunches that were difficult to separate. On media A and C, with $3 \mathrm{mg} \mathrm{BAP/liter,} \mathrm{the} \mathrm{shoots} \mathrm{were} \mathrm{well}$ developed and relatively large. Sometimes, however, tight bunches of shoots were ob- served on medium A. The best shoots in terms of color, size, and growth were obtained on medium E. 'Jonsok' shoots regenerated rapidly; the optimum stage was reached in 6 weeks of culture. Eight weeks of culture caused some degree of vitrification.

Pretreating 'Jonsok' donor plants on media containing hormones strongly affected the percentage of leaf disks producing shoots. The percentage of shoot-producing leaf disks was about three (medium D) to five times higher (medium C) than for those pretreated without hormones.

Pretreating 'Hiku' on G medium with hormones drastically increased shoot regeneration (Table 1). On medium $\mathrm{C}$, the increase was $\approx 16$ times higher with hormones than without hormones. Medium C also regenerated the highest number of shoots. Differences among regeneration media A-D were minimal and not significant.

With BAP at $5 \mathrm{mg} \cdot \operatorname{liter}^{-1}$ (media B and D) 'Hiku' shoot quality was not good. The shoots were small and not easily separated. BAP at 3 and $1.5 \mathrm{mg} \cdot \mathrm{liter}^{-1}$, however, produced wellformed, relatively large, and easily separated shoots. BAP at $1.5 \mathrm{mg} \cdot$ liter $^{-1}$, however, produced 3.1 shoots/TDN, whereas regeneration media A and C (3 mg BAP/liter) produced about three times more shoots. Both media seemed to provide equally favorable environments for shoot production.

The percentage of 'Hiku' leaf disks producing shoots varied little among the nutrient media, and the percentage was low after hormone pretreatment as well-only between 1.1 (medium A) and 1.8 (medium D) times higher than from leaf disks derived from plants pretreated on media without hormones.

Pretreating donor plants with hormones promoted shoot regeneration from 'Hiku' and 'Jonsok' leaf disks. Except for 'Hiku' grown on medium $\mathrm{B}$, the differences were significant at $P \leq 0.001$ in all cases; for 'Hiku' grown on medium $\mathrm{B}$, the difference was significant at $0.05 \geq P \geq 0.025$.

Pretreating explants with hormones also influences the subsequent success of tissue culture in Pinus pinaster Ait., where BAP promoted the morphogenesis of leaf explants (David et al., 1982). In mulberry (Morus alba L.), adventitious bud formation also was observed after BAP pretreatment (Oka and Ohyama, 1981).

Liu and Sanford (1988) found that $\mathrm{CH}$ and $\mathrm{KNO}_{3}$ stimulated shoot production from strawberry leaf tissue. In 'Hiku', medium C with increased $\mathrm{KNO}_{3}$ and decreased $\mathrm{CH}$ produced the highest number of shoots from leaf disks that originated from plants pretreated on $\mathrm{G}$ micropropagation medium with hormones, but the differences between medium $\mathrm{C}$ and media A, B, and D were not significant. However, in 'Jonsok', increasing $\mathrm{CH}$ and decreasing $\mathrm{KNO}_{3}$ (medium A vs. C) significantly improved shoot formation from leaf disks taken from plants not pretreated with hormones.

Contamination problems in tissue culture often occur in field- or greenhouse-grown plant materials; using in vitro-grown diseasefree or contamination-free material for cell and tissue culture studies or transformation may therefore be the method of choice. This study reveals that shoots can be regenerated directly from leaf disks, with a high regeneration rate, when in vitro-grown micropropagated plants are used.

\section{Literature Cited}

David, A., H. David, and T. Mateille. 1982. In vitro adventitious budding on Pinus pinaster cotyledons and needles. Physiol. Plant. 56: 102-107.

Evans, D.A. 1989. Somaclonal variation-Genetic basis and breeding applications. Trends Genet. 5:46-50.

George, E.F. and P.D. Sherrington. 1984. Plant growth regulators, p. 284-330. In: E.F. George and P.D. Sherrington (eds.). Plant propagation by tissue culture. Exegetics, Eversley, England.

Hicks, G.S. 1980. Patterns of organ development in plant tissue culture and the problem of organ determination. Bot. Rev. 46: 1-23.

James, D.J., A.J. Passey, and D.J. Barbara. 1990. Agrobacterium-mediated transformation of the cultivated strawberry (Fragaria xananassa Duch.) using disarmed binary vectors. Plant Sci. 69:79-94.

Jones, O.P., B.J. Wailer, and M.G. Beech. 1988. The production of strawberry plants from callus cultures. Plant Cell, Tissue Organ Culture 12:235241.

Liu, Z.R. and J.C. Sanford. 1988. Plant regeneration by organogenesis from strawberry leaf and runner tissue. HortScience 23: 1057-1059.

Murashige, T. and F. Skoog. 1962. A revised medium for rapid growth and bioassays with tobacco tissue cultures. Physiol. Plant. 15:473497.

Nehra, N.S., R.N. Chibbar, K.K. Kartha, R.S.S. Datla, W.L. Crosby, and C. Stushnoff. 1990a. Agrobacterium-mediated transformation of strawberrycalli and recovery of transgenic plants. Plant Cell Rpts. 9:10-13. 
Nehra, N.S., R.N. Chibbar, K.K. Kartha, R.S.S. Datla, W.L. Crosby, and C. Stushnoff. 1990b. Genetic transformation of strawberry by Agrobacterium tumefaciens using a leaf disk regeneration system. Plant Cell Rpts. 9:293-298.

Nehra, N.S., C. Stushnoff, and K.K. Kartha. 1989. Direct shoot regeneration from strawberry leaf disks. J. Amer. Soc. Hort. Sci. 114:1014-1018.
Nehra, N.S., C. Stushnoff, and K.K. Kartha. 1990c. Regeneration of plants from immature leaf derived callus of strawberry (Fragaria xananassa). Plant Sci. 66:119-126.

Oka, S. and K. Ohyama. 1981. In vitro initiation of adventitious buds and its modification by high concentration of benzyladenine in leaf tissues of mulberry (Morus alba). Can. J. Bot. 59:68-74.
Reinert, J. 1968. Morphogenese in Gewebe-und Zellkulturen, Naturwissenschaften 55:170-175. Uosukainen, M. 1991. G-basic medium, p. 34. In: F.O. Riordain (ed.). COST 87, Plant in vitro culture: Report of the 1991 activities. Commission of the European Communities, Biotechnol. Res. for Innovation, Dev. and Growth in Europe, Brussels. 